\title{
我が国に飛来する水鳥における Campylobacter属菌の保有状況
}

\author{
林谷秀樹 $^{1 *} \cdot$ 渡辺麻衣子 ${ }^{1} \cdot$ 茂田良光 $^{2} \cdot$ Alexandre Tomomitsu OKATANI $^{1}$ \\ 1東京農工大学農学部・ ${ }^{2}$ 山階鳥研
}

我が国に飛来するシギ・チドリ類やアジサシ類などの 旅鳥や夏鳥におけるCampylobacter属菌の保有状況を調査 し，これら病原体の自然界における生態に果たす渡り鳥 の役割について検討した。

\section{【材料と方法】}

供試材料として，1999年 4 月〜 11月までの 8 ケ月間に, 小櫃川河口（千葉県木更津市）および谷津干潟（千葉県 習志野市) の 2 地点で, 標識調查のために捕獲した 15 種 261 羽のシギ科およびチドリ科の水鳥の瓷便を供試材料と した。供試材料は， $5 \%$ 馬血液加Preston 液体培地に接種 し， $37^{\circ} \mathrm{C} て ゙ ~ 24$ 時間増菌培養後，その 1 白金耳を $5 \%$ 馬血 液加 Skirrow およびButzler 血液寒天平板培地に塗抹し, $37{ }^{\circ} \mathrm{C}$ で 48 時間微好気培養した。平板上に発育した Campylobacter属菌を疑うコロニーは, 純培養後, 各種生 化学性状を調べ同定した。

\section{【結＼cjkstart果】}

1. 供試した水鳥 261 羽中 207 羽 $(79.3 \%$ ）から Campylobacter属菌が分離された。このうちC.coliが204羽 (78.2\%)，C.lariが2羽 (0.8\%) およびC.jejuniが 1 羽 (0.4\%) から分離された。

2. 分離されたCampylobacter属菌207株は, RAPD法に より 26 パターンに型別された。この姿を捕獲時期別およ び鳥種別にみても, RAPDパターンの分布に大きな差は みられなかった。このことから, シギやチドリなどにお けるC.coliの高い保菌は, 特定のクローンが水鳥の集団に 流行したことによるものではなく，これらの水鳥はC.coli に対して高い親和性を持ち, C.coliは水鳥の腸管内の常在 フローラとなっていることによるものと推察された。

3. 分離されたCampylobacter属菌100株について, 抗生 物質 10 種に対する薬剂感受性を調べた結果， 1 株が （1\%）がOA，OFLXおよびCPFXに耐性を示した。水鳥 由来Campylobacter 属菌の耐性菌出現率は, 人や家畜由来 株に比較して低く，このことから水鳥由来株は人や家畜 との間の疫学的関連性は薄いものと思われた。

連絡先：林谷秀樹*

東京農工大学農学部獣医学科家畜衛生学研究室

T 183-8509 東京都府中市幸町 3-5-8

Tel \& Fax : 042-367-5775

E-mail : eisei@cc.tuat.ac.jp 


\title{
一般講演抄録（2）
}

\section{動物園等のは虫類における Salmonellaの保有状況}

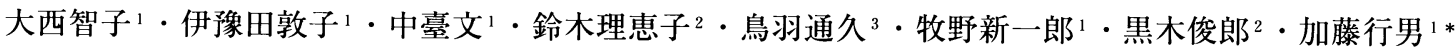 \\ ${ }^{1}$ 麻布大学獣医学部・2 神奈川県衛生研究所・ ${ }^{3}$ 日本蛇族学術研究所
}

近年, 輸入されるは虫類の数およびその種類は増加し ている。は虫類が Salmonella 高率に保有していること は従来から知られ, は虫類が感染源となったヒトのサル モネラ症の報告も少なからずあり, 海外では動物園で飼 育されているは虫類により小児がサルモネラ症に感染し たという事例も報告されている。また, 動物園では多種 の動物が飼育されているが, Salmonellaの感染により死 亡する動物園動物の存在が知られている。そこで今回, 動物園等で飼育されているは虫類の Salmonellaの保有状 況を調査し，その亜種および血清型を調べた。

\section{【材料と方法】}

供試材料は, 2001 年 11 月〜 2002 年 5 月の間に, 日本国 内の 3 力所の動物園等 $(\mathrm{A} \sim \mathrm{C}$ 施設) で展示用あるいは 研究用に飼育されているは虫類（95種類，132検体）から 採取した糞便を用いた。Salmonellaの分離は，前増菌培 地にBuffered Peptone Water，増菌培地にハーナ・テ トラチオン酸塩培地, 分離培地にDHL寒天培地, ESサル モネラ寒天培地 II , ノボビオシン加ブリリアントグリー ン寒天培地, MLCB 寒天培地を用いた。各分離培地上に 発育したSalmonella 疑うコロニーは, 純培養後, 各種 生化学性状を調べ同定した。Salmonella と同定された株 については，生化学性状により亜種を決定するとともに 市販免疫血清を用い血清型別を行った。

\section{【結果と考察】}

動物園等の 3 施設で飼育されているは虫類 132 検体中 74 検体 $(56.1 \%)$ から Salmonellaが分離された。这虫類 の種類によるSalmonellaの分離率は，トカゲ類 81.5\% (22/27), ヘビ類 71.9\% (46/64), カメ類 15.4\% (6/39), ワニ類 0\% (0/2) で, トカゲ類, ヘビ類で高率であった。 S. entericaの亜種別では, subsp. enterica（I）が36検体, subsp. salamae（II）が14検体, subsp. arizonae（III a）が 6 検体, subsp. diarizonae (III b) が 32 検体, subsp. houtenae（IV）が10検体から分離された。優勢に分離さ れた亜種は施設によって異なり，A施設では亜種 I が, $\mathrm{B}$ 施設では带種 III bが最も多かった。C施設では亜種 I と而bが同程度に多く分離された。注虫類 36 検体から分 離された带種 I 39株は，14種類の血清型に型別された。 血清型を施設別にみると，A施設では $S$. Poanoが最も多く 8 検体から, 次いで $S$. Newportが 4 検体で, C施設では $S$. NewportおよびS. Osloが各 3 検体であった。

以上のことより，動物園等の施設で飼育されているは 虫類は，Salmonella を高率に保有し，保有している Salmonellaの亜種あるいは血清型は各施設で異なってい ることが示唆された。

\section{連絡先 : 加藤行男*}

麻布大学獣医学部獸医学科公衆衛生第二研究室

于 229-8501 神奈川県相模原市淵野辺 1-17-71

Tel : 042-754-7111

Fax : 042-769-1649

E-mail : katohy@azabu-u.ac.jp 


\title{
一般講演抄録（3）
}

\section{牛サルモネラ症の実態調查}

\author{
志村亀夫*・山根逸郎・筒井俊之・濱岡隆文
}

独立行政法人動物衛生研究所

牛のサルモネラ症は, 子牛に下痢や敗血症を引き起こ すことから大規模乳雄子牛肥育経営などにとって大きな 損耗要因である。更に 1970年代後半に Salmonella Dublin による繁殖和牛のサルモネラ症が発生し，また Salmonella Typhimuriumによる搾乳牛でのサルモネラ症 が90年代に入って全国的に増加してきた。その発生要因 として, 乳牛の高泌乳化が指摘され，高泌乳を支える高 蛋白・高エネルギー飼料の過剩給与が成牛でのサルモネ ラ症の大きな要因であるとされてきた。そこで，成牛型 サルモネラ症を中心に，牛の飼養環境に打けるサルモネ ラ污染の効率的な防除を可能とする管理上のポイントを 明らかにする目的で調查を実施した。

牛のサルモネラ症例の基本的な疫学的特徵を把握する 目的で，1998年度及び1999年度に届出のあった 31 道府県 61 症例を対象にして，届出症例を管轄した家畜保健衛生 所にアンケート調査を実施した。調査では，経営形態， 飼養規模, 酪農の場合の平均乳量, 発生時期, 発生届出 頭数と発症と保菌の内訳，流行全体の摘発頭数，環境等
からのサルモネラ検出実態などを調査した。その結果， 発生農家での感染率は乳用牛では $28 \%$ と高いが, 肉用牛 では $0.9 \%$ と低いこと, 発生は乳用牛, 肉用牛ともに 7 月 から 9 月の気温の高い時期に多いことが明らかとなった。 また，原因別では，Salmonella Dublinは肉用子牛で, Salmonella Typhimurium は乳用成牛で本症の主要原因と なっていた。発生から清浄化までの平均病日は 60.5 日 17.5 日であり, 発生頭数が多いと長期化する傾向があっ た。

そこで，成牛型 Salmonella Typhimurium 発生農家にお ける発生の危険因子を解明するために 2001 年度に 6 県 19 農家を対象としてアンケートによる症例対照研究を行っ た。調查項目は, 経営形態, 施設, 侵入動物, 衛生管理, 初発牛を調查した。その結果, 飼育頭数, 平均泌乳量な どの経営形態に関する量的なデータで差は認められず, 発生の要因としては, 外来性の要因よりも, 対頭式繋ぎ, 餌槽の仕切り板, 敷料の有無などの飼育管理が危険因子 として示唆された。

連絡先：志村亀夫*

（独）動物衛生研究所実験動物管理科

干 305-0856 茨城県つくば市観音台 3-1-5

Tel : 0298-38-7953

Fax : 0298-38-7907

E-mail : kameos@affrc.go.jp 


\title{
牛乳房炎発生に関わる要因分析
}

\author{
山根逸郎*・筒井俊之・志村亀夫
}

独立行政法人動物衛生研究所

牛の乳房炎は, 酪農の生産現場では大きな経済的損失 をもたらす疾病として問題となっている。乳房炎の発生 には, 給与飼料バランスや畜舎構造などの飼養形態や, 搾乳衛生の不備など, 複数の要因が複雑に関与している と言われている。今回, 疫学的な調查によりデー夕を収 集し, 乳房炎の発生に関わる各種要因と乳房炎の発生と の相互関係を明らかにし，乳房炎防除に重要な衛生対策 について検討を行った。

\section{【材料・方法】}

北海道の各家畜保健衛生所が管轄する農家で, 搾乳牛 の飼養頭数 10 頭以上で牛群検定を行っている農家を 84 軒 （6軒×14家畜保健衛生所）選定した。それぞれの農家に 対して, 飼養管理, 搾乳衛生や飼料内容などに関するデ 一夕，対象期間中（平成 11 年 1 年間）に発生した乳房炎 の数と種類, 分離細菌名, 治療内容などに関するデー夕, 牛群検定結果などを収集した。乳房炎の発生状況の指標 については，乳房炎の発生率を下記のように定義した。

乳房炎発生率 = 一定期間内に新規に発生した乳房炎数 / (対象動物数 $\times$ 対象期間 (月))

これらのデー夕を取りまとめ, 各種要因と乳房炎発生 との関係を解析した。さらに乳房炎牛から細菌の分離を 試みた農家を対象に, 黄色ブドウ球菌, コアグラーゼ陰 性ブドウ球菌，連鎖球菌，大腸菌群の分離された乳房炎 の発生率を上記と同様に算出して, 各種要因との関連を 解析した。

\section{【結 果】}

フリーストール農家など, 比較的大規模な農家におい て発生率が低く，また平均乳量の高い農家において発生 率が低い傾向が認められた。また牛床が適切な長さの農 家やリターン式のディッピング容器を使用している農家, 通路を毎日清掃する農家において発生率が低かった。

黄色ブドウ球菌の分離された乳房炎に関しては，搾乳 前の手指の消毒やディッピング容器の種類, プレディッ ピングの実施の有無, 塩素片によるラインの消毒温度, 牛舎の材質などの項目において発生率に差が認められた。 コアグラーゼ陰性ブドウ球菌の分離された乳房炎に関し ては, 乳房炎が治癒しない牛の淘汰と害虫駆除の項目で 発生率に差が認められた。連鎖球菌が分離された乳房炎 に関しては, 手指の消毒頻度, ディッピング容器の形態, 牛床の長さ, 乳房炎が治癒しない牛の淘汰などの項目で 発生率に差が認められた。大腸菌群が分離された乳房炎 に関しては, 他の細菌による乳房炎の発生率の場合と異 なった傾向を呈し, 布の管理, ディッピング容器の種類, 塩素剤による消毒温度, 牛床の長さ, 牛床の消毒頻度な どの項目で発生率に差が認められた。

\section{【考 察】}

上記のように，乳房炎牛から分離される細菌の種類に 応じて, 各種要因の乳房炎の発生率に与える影響が異な るため, 乳房炎の種類に応じて発生メカニズムが異なる ことが考えられた。今後，農家において多発する乳房炎 の種類に応じたきめ細やかな衛生対策指導などの必要性 が考えられた。

連絡先：山根逸郎*

(独) 動物衛生研究所疫学研究部予防疫学研究室

テ 305-0856 茨城県つくば市観音台 3-1-5

Tel : 029-838-7770

Fax : 029-838-7880

E-mail :iyamane@affrc.go.jp 


\title{
国内繁殖豚群農場における哺乳中死亡率の記述疫学と他の生産指標との相関
}

\author{
中村遼子・纈攧雄三* \\ 明治大学農学部
}

哺乳中死亡率は, 群の繁殖生産性の指標である年間雌 豚当り離乳子豚数と強い関連があると報告されているが, 国内繁殖豚群農場における哺乳中死亡率の調查例は少な い。そこで, 本研究では農場群における哺乳中死亡率を 疫学的に記述し, かつ他の生産指標との関係を明らかに することで死亡率改善と生産性向上の一助にしたいと考 えた。

\section{【材料・方法】}

2002年に生産記録の管理・分析にコンピュータ生産記 録ソフト（Pig CHAMP：ミネソタ大学・米国）を使用し ている生産者と獣医師に生産記録の提供を依頼した。集 計分析の観察単位は農場であり, 哺乳中死亡率は分婏・ 離乳母豚の生存産子数の群合計と分娩・離乳母豚の離乳 子豚数の群合計との差を分婏・離乳母豚の生存産子数の 群合計で割って算出した。まず，2001年の各年間生産指 標の記述統計を行った（SAS；1988）。そして産歴（初 産・ 2 産・ 3-5産・6産以上), 月 $(1-3 \cdot 4-6 \cdot 7-$ $9 \cdot 10-12$ 月), 5 年 $(1997-2001$ 年) の傾向, 地区によ る死亡率の比較と, 子豚の死亡日令 $(0-1 \cdot 2-7 \cdot 8-$ $14 \cdot 15$ 日令以上), 月 $(1-3 \cdot 4-6 \cdot 7-9 \cdot 10-12$ 月) による記録された理由別の比例死亡率の比較を One-Way ANOVAと多重検定を用いて行った。最後に哺乳中死亡率 と他の生産指標との相関関係を Pearson correlationを用い て求めた。

\section{【結 果】}

全国117農場から 16 県 107 農場の生産記録が提供されたが 2戸は肥育農場であった為, 実際には 105 農場の生産記録 を用いた。農場の所在地区の内訳は北海道・東北地区が

\footnotetext{
連絡先：纈纈雄三*

明治大学農学部農学科動物生産学

T 214-8571 神奈川県多摩市東三田 1-1-1

Tel : 044-934-7826

Fax : 044-934-7902

E-mail : koket001@isc.meiji.ac.jp
}

33 戸，北陸地区が18戸，関東地区が 16 戸，中部地区が 21 戸，九州地区が17戸であった。105農場の平均雌豚数は $267.5 \pm 32.0$ 頭 (平均 $\pm \mathrm{SEM}$ ), 変動幅は $30-2887$ 頭であ った。母豚の産歴は $2.8 \pm 0.06$ 産, 平均授乳期間は $21.8 \pm$ 0.23 日であった。

平均哺乳中死亡率は $10.4 \pm 0.13 \%$, 変動幅は $3.3-$ $22.8 \%$ であった。中央值は $10.7 \%$, 最頻值は $10-11 \%$ で あった。3産以上の母豚（3-5産は $12.3 \pm 0.39 \% ， 6$ 産以 上は $13.9 \pm 0.57 \%$ ）は低産次の母豚（初産は $6.53 \pm$ $0.55 \% ， 2$ 産は $6.42 \pm 0.54 \%)$ よりも哺乳中死亡率の值が 大きかった $(\mathrm{P}<0.05)$ 。月による生産指標の推移は, 哺乳 中死亡率は $7-9$ 月に高く $(11.9 \pm 0.42 \%), 4-6$ 月に低 く $(9.40 \pm 0.34 \%)$ なった $(\mathrm{P}<0.05)$ 。 5 年間では哺乳中死 亡率に有意差はみられなかった。地区による哺乳中死亡 率は8.85-13.5\%とバラッキがみられた。

子豚の比例死亡率は虚弱 $(38.5 \pm 1.75 \%)$, 外傷 $(37.7 \pm 1.68 \%)$, 下痢 $(6.31 \pm 0.91 \%)$, その他 $(6.26 \pm$ $1.12 \%)$, 餓死 $(4.12 \pm 0.90 \%)$, 先天的疾患 $(3.27 \pm$ $0.29 \%)$, 不明 $(2.04 \pm 1.31 \%)$, 疾病 $(1.72 \pm 0.36 \%)$ の 順になった。死亡日令による比例死亡率の比較では先天 的疾患, 外傷による死亡率は $0-1$ 日令に高く（外傷は $55.8 \pm 2.23 \%)$, 疾病による死亡率は 15 日令以上 $(8.61 \pm$ $1.42 \%)$ に高かった $(\mathrm{P}<0.05)$ 。月による死亡率の比較で は外傷による死亡率が7 - 9月 $(41.7 \pm 1.87 \%)$ に高かっ た $(\mathrm{P}<0.05)$ 。

哺乳中死亡率と一腹当り生存産子数との間には正の相 関があったが $(r=0.42, \mathrm{P}<0.01)$, 年間雌豚当り離乳子豚数 との間には負の相関があった $(\mathrm{r}=-0.25, \mathrm{P}<0.01)$ 。哺乳中死 亡率と授乳期間との間には正の相関があり $(\mathrm{r}=0.21, \mathrm{P}<0.05)$, 平均雌豚在庫頭数との間には相関はなか った。 


\title{
都心部家庭飼育の小型犬における乳腺腫瘍の発生状況
}

\author{
橋本志津 $\cdot$ 山村穂積 ·酒井健夫* \\ 日本大学生物資源科学部
}

乳腺腫瘍は, 雌犬で最も多発する腫瘍性疾患であるが, わが国における犬の乳腺腫瘍の発生状況, 病態ならびに 術後の状態については十分明らかにされていない。しか し, 乳腺腫瘍の診断時にこれらの要因が明らかにされて いれば治療方針を決定する上で有用である。そこで，演 者らは犬の乳腺腫瘍を臨床疫学的に解明することを目的 として，わが国都心部の家庭で飼育されている小型犬の 乳腺腫瘍の発生状況を調查した。調查項目は, 乳腺腫瘍 の罹患犬種, 年齢, 腫瘍の大きさと発生部位抢よび病理 組織学的所見であった。

乳腺腫瘍は，1996年から 2000 年に来院した小型犬雌 2538 例のうち 21 犬種 201 例に認められ, 乳腺腫瘍の発生 率は $7.9 \%$ であり, 乳腺腫瘍摘出時の平均年齢は 8.5 歳で あった。乳腺腫瘍の発生は犬種によって異なり, ミニチ ユアシュナウザー, マルチーズ，シェットランドシープ ドッグおよびヨークシャーテリアで多く認められた。
症例の腫瘍摘出時の年齢は $4 \sim 17$ 歳に分布した。乳腺 腫瘍の大きさが直径 $3 \mathrm{~cm}$ 未満の場合が発生症例の $80.6 \%$ を占め, 発生部位では下位乳腺が上位乳腺に比べて約 2 倍多かった。病理組織学的所見では，悪性腫瘍症例は $93.0 \%$ ，良性腫瘍症例は7.0\%であった。また，乳腺腫瘍 の分類別症例数は, 複数の乳腺腫瘍を伴っている場合を 含めると, 乳腺癌は 75 症例, 乳管内乳頭状腺癌は 50 症例, 乳腺悪性混合腫瘍は 135 症例, 乳腺良性混合腫瘍は 46 症 例, 乳腺悪性筋上皮腫は 3 症例, および乳腺良性筋上皮 腫は 3 症例であった。

以上, 乳腺腫瘍の発生に犬種による差が見られたが, 年齢, 腫瘍の大きさと発生部位抢よび病理組織学的所見 では差は認められず，発生した乳腺腫瘍の多くが悪性腫 瘍であり，罹患犬を評価する上でこれらを考慮する必要 性があるものと判断された。

連絡先：酒井健夫*

日本大学生物資源科学部獣医衛生学研究室

干 252-8510 神奈川県藤沢市龟井野 1866

Tel \& Fax : 0466-84-3650

E-mail : sakai@brs.nihon-u.ac.jp 
一般講演抄録

一般講演抄録（7）

\title{
微生物学的リスクマネージメントにおけるリスクアセスメントの利用 - Food Safety Objectiveの導入について
}

\author{
春日文子* \\ 国立医薬品食品衛生研究所
}

国際食品微生物規格委員会 (ICMSF) から提案され, $\mathrm{FAO} / \mathrm{WHO}$ 専門家会議等で議論されている, 微生物学的 リスクマネージメントにおけるリスクアセスメントの利 用のあり方について，ご紹介する。

食品衛生上の微生物学的な問題に関して,リスクマネ ージメントのためにリスクアセスメントが必要とされる のは，主として新たに定量的規格基準の設定が必要とな りそのために科学的根拠が要求される場合，貿易摩擦な どに関連して二国間又は多国間の規格基準等法的規制の 同等性を評価する必要がある場合，フードチェーン全体 を見通して効果的な対策を提示する必要のある場合，と の部分の知見が不足しているのかを整理し研究費の有効 利用を促進する場合，などである。

食品の微生物学的リスクに対しては，それをゼロにす るのは実際上不可能であり，むしろ国民が納得できるリ スク低減の目標值を設定しよう，という概念が受け入れ られるようになってきた。例えば，今後 10 年以内に Campylobacterによる食中毒を 4 分の 1 にしよう，という のは目標設定の例であり, 目標のレベルはAppropriate Level of Protection (ALOP) あるいはTolerable Level of Risk（TLR）と呼ばれる。これらの目標レベルは一定の人 口中の患者数を用いて表わされる。この值を設定するた めには，現状の実際の患者数をできるだけ正確に推定し
なければならない。現在の食中毒統計も感染症法に基づ く疾病統計や病原体検出統計も，それぞれに限界があり， そこに現れる数字は実患者数のごく一部である。そのよ うな限界を伴う疫学デー夕と微生物学的リスクアセスメ ントによる推計值とを相互補完的に考察しながら，患者 実数の推定が行われる。その推定值をもとに，十分なリ スクコミュニケーションを行なった上で, ALOPPTLR が設定される。

さらに, ALOPは, 食品中の微生物の存在頻度と菌数, という検証可能な数值に変換される必要がある。ICMSF が提唱している考え方の中では，そのためにまず, ALOP を充たす喫食時点の污染頻度と菌数の最大值を算定し, これを Food Safety Objectives（FSO）と定義するとされて いる。ALOP からのFSO の算定は, 微生物学的リスクア セスメントに扔ける摂食菌数-発症率相関 (doseresponse assessment）を逆算することで可能になる。加 工段階や生産段階で, 実際に微生物学的検査により検証 しうる微生物的基準や規格（Microbiological criteria, Performance criteria) は，まずFSOを基準とし，定量的 なリスクアセスメントの中でフードチェーンを解析して きた流れを逆に辿ることにより設定していく，という方 向性が提案されている。

\footnotetext{
連絡先：春日文子*

国立医薬品食品衛生研究所安全情報部第二室

干 158-8501 東京都世田谷区上用賀 1-18-1

Tel：03-3700-1141内線（572or538）

Fax : 03-3700-1483

E-mail : kasuga@nihs.go.jp
} 